POSSAMAI, A.J. et al. Influência da adubação fosfatada e calagem na ecofisiologia de gramíneas forrageiras. PUBVET, Londrina, V. 8, N. 8, Ed. 257, Art. 1705, Abril, 2014.

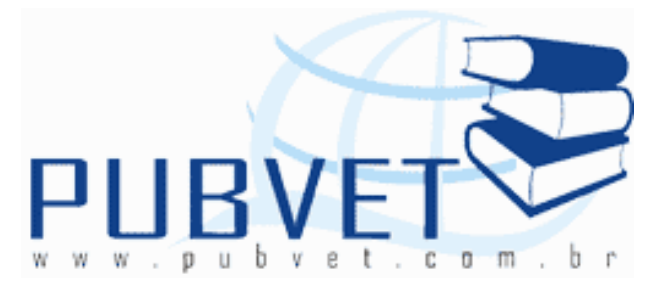

PUBVET, Publicações em Medicina Veterinária e Zootecnia.

\title{
Influência da adubação fosfatada e calagem na ecofisiologia de gramíneas forrageiras
}

\section{Adriano Jorge Possamai ${ }^{1} *$, Lucien Bissi da Freiria ${ }^{1}$, Alan Carlos Barboza ${ }^{2}$, Pedro} Ivo Jose Lopes da Rosa e Silva ${ }^{3}$, Joanis Tilemahos Zervoudakis ${ }^{4}$

${ }^{1}$ Discente Mestrado Programa de Pós-Graduação em Ciência Animal - UFMT Cuiabá - MT

2 Discente Graduação em Zootecnia pela Universidade Federal de Mato Grosso UFMT - Cuiabá - MT

${ }^{3}$ Discente Graduação em Medicina Veterinária pela Universidade Federal de Mato Grosso UFMT - Cuiabá - MT

${ }^{4}$ Professor Associado Departamento de Ciências Básicas e produção Animal UFMT Cuiabá - MT

* Autor para correspondência: possamai.a.j@gmail.com

\section{Resumo}

Objetivou-se buscar estudos que mostrassem a influência da adubação fosfatada e calagem na ecofisiologia de plantas forrageiras. O Fósforo é um elemento fundamental para a fisiologia vegetal participando do processo de obtenção de energia. No entanto é comum a deficiência deste elemento nos solos, assim a adubação com este elemento é amplamente testada. A amplitude da resposta varia com o tipo de planta, do solo, da inter-relação com outros nutrientes, no entanto observa-se resposta crescente amedida que 
POSSAMAI, A.J. et al. Influência da adubação fosfatada e calagem na ecofisiologia de gramíneas forrageiras. PUBVET, Londrina, V. 8, N. 8, Ed. 257, Art. 1705, Abril, 2014.

se aumenta a dosagem do fósforo, ocorre aumento na densidade dos perfilhos, aumento da massa das raízes, aumento do teor de fósforo nas folhas. Já a acidez é o problema mais discutido em solos tropicais sendo que o produto mais utilizado na calagem é o calcário e a resposta a calagem pode ser positiva, negativa dependendo de outros fatores. A mobilidade no solo do calcário e do fósforo é baixa, assim a resposta da planta fica susceptível a influência de outros fatores como a disponibilidade de outros nutrientes.

Palavras-chaves: Brachiaria spp.; Crescimento de forragens; Fertilizantes; Panicum spp.

\section{Influence of phosphorus fertilization and lime in the grass forage ecophysiology}

\section{Abstract}

The objective was to search studies that showed the influence of phosphorus fertilization and limestone on the ecophysiology of forage plants. Phosphorus is an essential element for plant physiology participating in the process of obtaining energy. However it is common deficiency of this element in the soil, thus fertilizing with this element is extensively tested. The magnitude of the response varies with the type of plant, soil, interrelation with other nutrients, however response observed growing as it increases the dosage of phosphorus, there is increase in the density of tillers, increased mass roots, increasing the phosphorus content in the leaves. Already acidity is the most discussed issue in tropical soils being the most used product in lime is limestone and response to liming can be positive, negative, depending on other factors. Mobility in soil calcium and phosphorus is low, so the response of the plant is susceptible to the influence of other factors such as the availability of other nutrients.

Keywords: Brachiaria spp, fertilizers, Growing forage, Panicum spp. 
POSSAMAI, A.J. et al. Influência da adubação fosfatada e calagem na ecofisiologia de gramíneas forrageiras. PUBVET, Londrina, V. 8, N. 8, Ed. 257, Art. 1705, Abril, 2014.

\section{INTRODUÇÃO}

O Brasil conta com um rebanho de 209,5 milhões de bovinos (IBGE, 2010), sendo considerado o maior rebanho comercial do mundo, deste montante aproximadamente $7 \%$ é terminado em confinamentos, o restante permanece em regime exclusivamente a pasto, que decorrente da sazonalidade de oferta de forragem aliada a não intervenção do homem no manejo alimentar do gado e no manejo correto das pastagens promove índices produtivos baixos, como taxa de desfrute insatisfatória, intervalo entre partos prolongado, idade avançada ao abate dentre outros(PAULINO et al., 2012).

Como a maioria de nosso rebanho é mantido em regime de pastejo a área de pastagem destinadas a pecuária brasileira é 163 milhões de ha (IBGE, 2010), sendo esperado diante desta imensidão de terras utilizadas encontrarmos áreas subutilizadas ou superutilizadas, decorrente da aplicação de uma manejo inadequado da pastagem, o que nos leva a ter $70 \%$ da área total em algum estágio de degradação, montante este que totaliza uma área de aproximadamente 115 milhões de hectares (ZIMMER e MACEDO, 2010).

A degradação das pastagens foi definida por Macedo et al. (2000) como sendo um processo evolutivo acompanhado de perda de vigor, produtividade e da capacidade de recuperação natural das pastagens para que se mantenha os níveis adequados de produção, o que levará a degradação avançada dos recursos naturais, para este autores ainda esta perca na capacidade produtiva decorrente do empobrecimento do solo leva os pecuaristas a uma busca por novas pastagens, e caminham neste sentido sempre em direção das plantas menos exigentes e por consequência menos nutritivas, desta maneira a utilização de corretivos agrícolas aliados a praticas adequadas de manejo são essenciais para se manter a produtividade de uma dada área.

As causas da degradação das pastagens estão correlacionadas aos fatores de estabelecimento de forrageiras e de manejo, sendo que a escolha incorreta da gramínea leva a uma má formação inicial, sendo este ponto determinante para a degradação da forrageira, associada a falta de fertilidade 
POSSAMAI, A.J. et al. Influência da adubação fosfatada e calagem na ecofisiologia de gramíneas forrageiras. PUBVET, Londrina, V. 8, N. 8, Ed. 257, Art. 1705, Abril, 2014.

e adubação de manutenção. O manejo inadequado do pastejo também ajuda a levar a gramínea à degradação (ZANINE et al., 2005).

A disponibilidade de nutrientes do solo à planta assim como de água dependem de interações entre complexos fisiológicos, celulares, além de processos iônicos de transporte e mobilidade destes nutrientes no solo, sendo que a acidez do solo, teores de alumínio, e capacidade de adsorção, interferem nas taxas de captação e aproveitamento dos nutrientes pela planta (REZENDE et al., 2011).

Depois do Nitrogênio o Fósforo é o nutriente que mais limita o crescimento das forrageiras, sua deficiência limita a capacidade produtiva das pastagens, sendo que os solos destinados a pratica de agropecuária no Brasil são em sua maioria deficientes nestes elementos (NOVAIS e SMYTH, 1999).

Outro fator ligado a déficit de produção é o excesso de acidez nos solos brasileiros, associados ao excesso de alumínio, que prejudicam a disponibilidade de nutrientes,além do crescimento radicular das plantas, abrangendo não somente a camada superficial mais também a camada subsuperficial (RAMOS et al., 2006). Já Hartwiget al. (2007) descrevem que cerca de $50 \%$ dos solos agricultáveis do mundo são considerados ácidos apresentando $\mathrm{pH}<5,5$ o que pode limitar a produção de gramíneas mais sensíveis em certas áreas.

Nesta revisão busca-se encontrar dados da influência da adubação fosfatada e da calagem no desenvolvimento de gramíneas forrageiras, revisando trabalhos que mensuram produção de matéria seca (MS), número de perfilhos, densidade de perfilhos, massa de raízes ou outras características relacionadas à capacidade produtiva das gramíneas forrageiras cultivadas no Brasil.

\section{IMPORTANCIA DO FÓSFORO PARA A PLANTA}

Para Rosanova (2008) o fósforo é o nutriente que mais limita o crescimento de forrageira em solos tropicais, uma vez que a deficiência de $P$ nestes solos é generalizada, dificultando o estabelecimento e manutenção das 
POSSAMAI, A.J. et al. Influência da adubação fosfatada e calagem na ecofisiologia de gramíneas forrageiras. PUBVET, Londrina, V. 8, N. 8, Ed. 257, Art. 1705, Abril, 2014.

forrageiras. O fósforo desempenha papel fundamental no desenvolvimento das raízes, bem como na produção de novos perfilhos, sendo assim um nutriente essencial para maior produtividade e resistências das gramíneas (SANTOS et al., 2006 apud ROSANOVA, 2008).

Segundo Novais e Smyth (1999) a concentração de $P$ no solo pode ser alterada pela adição de fósforo no solo de origem mineral, sendo esta a disponibilizada via fertilizantes oriundos de rochas, os quais podem apresentar diferentes graus de solubilidade para produzir a P-Solução que será disponibilizada para absorção da planta. Ou ainda via fontes orgânicas que formará a P-Solução após sofrerem mineralização pela biomassa microbiana. No entanto esta fonte pode ter parte do $P$ retido para que exista crescimento da massa de microrganismo.

Para Santos e Kliemann (2006) o fósforo apresenta grande capacidade de adsorção ao solo, ou seja, a ligação com partículas do solo tornando-o indisponível para a planta. Assim o P-lábil com o tempo passa para a forma não lábil que constituirá o $\mathrm{P}$ indisponível à planta.

A absorção do $\mathrm{P}$ contido no solo será determinada pela distância que este nutriente encontra-se das raízes, assim quanto maior o contato maior será a absorção, já que o fósforo apresenta baixa mobilidade no solo, neste sentido as gramíneas são favorecidas, dada sua estrutura radicular que é bem disseminada, aumentando a superfície de contato com os nutrientes em solos onde sua disponibilidade não é alta (BARRETO e FERNANDES, 2002).

O Fósforo tem importantes funções no metabolismo da planta, principalmente para os processos energéticos, dado ao fato de ser componente principal do ATP, o $P$ então é necessário na conversão da energia luminosa em energia química durante o processo de fotossíntese. Outro papel atribuído ao fósforo é a modificação do papel de diversas enzimas por fosforilação, além de ser utilizado na biossíntese de várias biomoléculas, fundamentando mais uma vez sua importância no crescimento vegetal e por consequência na produção de biomassa (TAIZ e ZEIGER, 2004). 
POSSAMAI, A.J. et al. Influência da adubação fosfatada e calagem na ecofisiologia de gramíneas forrageiras. PUBVET, Londrina, V. 8, N. 8, Ed. 257, Art. 1705, Abril, 2014.

O suprimento inadequado de fósforo reduz a taxa de fotossíntese da folha por reduzir a área foliar total, além de reduzir o número de folhas. Desta maneira a assimilação de $\mathrm{CO}_{2}$ é prejudicada. Associado a estes fatores a deficiência de fósforo ainda pode limitar o transporte de fotoassimilados e a condutância estomática é prejudicada, aumenta-se a quantidade de $\mathrm{CO}_{2}$ intercelular levando a uma limitação na capacidade fotossintética da gramínea forrageira prejudicando ainda mais a produção de biomassa deste vegetal, 0 aumento na disponibilidade do fósforo eleva a atividade e renovação celular e por consequência o índice de iniciação e senescência das folhas, por haver incremento na taxa fotossintética foliar (MARTINS, 2010).

Entretanto Rezende et al. (2011) apontam que o principal papel do fósforo esta relacionado com o desenvolvimento do sistema radicular e no perfilhamento das gramíneas, assim sua deficiência ira limitar a taxa de crescimento inicial das forrageiras bem como seu potencial produtivo e as respostas da planta a adubação só são potencializados quando a disponibilidade de outros nutrientes não sejamlimitante.

Dada a importância do fósforo para a planta Rossi e Monteiro (1999), descreveram que os métodos para a diagnose da deficiência de $P$,em Brachiaria Decumbens e Panicum maximum cv. Colonião, estão relacionados a análises químicas dos tecidos das plantas, métodos visuais além de método enzimático, utilizando como indicador bioquímico a enzima fosfatase ácida.

Corroborando com os dados encontrados por França e Haag (1985) que pesquisando os sinais de deficiência de fósforo em Panicum maximumjacq. Tobiatã, em casa de vegetação onde os outros nutrientes não eram limitantes encontraram crescimento extremamente lento, com alteração na coloração das folhas que se tornaram verdes mais escuras, além das folhas inferiores secarem prematuramente. A produção de perfilhos na deficiência de fósforo representou apenas $4,81 \%$ da produção total de perfilhos para as plantas que estavam com suprimento adequado de $P$.

Martins (2010) percebeu que o aumento na disponibilidade de fósforo para a planta, promove um aumento linear na concentração deste elemento 
POSSAMAI, A.J. et al. Influência da adubação fosfatada e calagem na ecofisiologia de gramíneas forrageiras. PUBVET, Londrina, V. 8, N. 8, Ed. 257, Art. 1705, Abril, 2014.

nas folhas recém-expandidas, tanto após a germinação como após o corte. Sendo que o índice de utilização do fósforo decresceu linearmente com o aumento da disponibilidade do nutriente.

A fonte principal de $\mathrm{P}$ na natureza é a rocha fosfatada (apatita), Os fosfatos naturais podem ser de origem vulcânica (ígneas), os quais são de baixíssima solubilidade tanto em água como em ácido e, portanto, com eficiência agronômica próxima de zero. Os fosfatos naturais de origem sedimentar têm maior substituição isomórfica em sua estrutura o que a torna mais frágil e, portanto, mais reativo. A eficiência agronômica dos fosfatos naturais reativos é variável, dependendo das condições de solo. O ácido fosfórico $\left(\mathrm{H}_{3} \mathrm{PO}_{4}\right)$ é a principal matéria-prima para a fabricação dos principais fertilizantes fosfatados. Sendo os que mais são utilizados na correção do solo são os superfosfatos simples ( 18 a $20 \%$ de $\mathrm{P}_{2} \mathrm{O}_{5}$ ), fosfatos bicálcicos com ( $20 \mathrm{a}$ $40 \%$ de $\mathrm{P}_{2} \mathrm{O}_{5}$ ), superfosfato triplo com ( 42 a $48 \%$ de $\mathrm{P}_{2} \mathrm{O}_{5}$ ) e os fosfatos de amônio com teores entre (55 a 62\%) de $\mathrm{P}_{2} \mathrm{O}_{5}$, bem como formulações específicas dos fertilizantes NPK (NOVAIS e SMYTH, 1999).

Como existem estas diferentes fontes de $\mathrm{P}$ para utilização como fertilizante Bernadi e Cardoso (2011) testaram 5 doses de $\mathrm{P}_{2} \mathrm{O}_{5}(0 ; 50 ; 100$; 200 e300 kg/ha) oriundo de 3 diferentes fontes (Superfosfato triplo, fosfato de rocha de Marrocos e de Cajati) na implementação de Medicago sativa, em argissolo de textura média com $80 \%$ de saturação de base, e concluíram que a produção de MS é linear crescente para o aumento nas dosagens de $\mathrm{P}$ sendo solúveis ou não e que a fonte de $\mathrm{P}$ solúvel (Superfosfato Triplo) foi $28 \%$ inferior ao fosfato de Marrocos na produção de MS e mesma para o fosfato de Cajati que apesar de apresentar menor solubilidade houve tendência ao longo do ciclo que os resultados destas fontes se aproximem da fonte solúvel.

Estes dados justificam o predito por Santos e Kliemann (2006) em que a utilização de fontes de fósforo que possuam menor solubilidade em água podem melhorar a eficiência de utilização do elemento pelas plantas, uma vez que a liberação seria lenta e a planta teria capacidade de absorver o fósforo na 
POSSAMAI, A.J. et al. Influência da adubação fosfatada e calagem na ecofisiologia de gramíneas forrageiras. PUBVET, Londrina, V. 8, N. 8, Ed. 257, Art. 1705, Abril, 2014.

medida que estivesse formando a P-Solução, diminuindo o índice de perca por adsorção.

\section{UTILIZAÇÃO DO FÓSFORO EM CULTURA DE GRAMÍNEAS FORRAGEIRAS}

São vários os trabalhos que buscaram a influência da adubação fosfatada no desenvolvimento de gramíneas forrageiras. Rossi \& Monteiro (1999) estudando 3 doses de fósforo $\left(3,1 ; 15,5 ; 31 \mathrm{mgl}^{-1}\right)$ em solução aplicado em Brachiaria decumbens e Panicum maximum, mantidos sob condições ótimas em casa de vegetação e verificaram interação entre as doses de fósforo e a produção de matéria seca tanto da parte aérea com das raízes com os ambos os capins. Verificaram ainda que as exigências deste nutriente para o gênero Brachiaria sãocrescentes à medida que a planta se desenvolve. No entanto o gênero Panicum apresentam maiores exigências em relação aBrachiariaspdesde as fases iniciais das plântulas.

Outro trabalho na tentativa de encontrar os níveis críticos de $\mathrm{P}$ no solo por plantas forrageiras foi conduzido por Santoset al. (2002), que trabalharam com Brachiaria decumbens e Panicum maximum de diferentes idades pós emergência utilizando cinco doses de $P\left(0,64,128,320\right.$ e $\left.640 \mathrm{mg} / \mathrm{dm}^{3}\right)$ durante crescimento inicial e rebrota. A produção de MS inicial foi $20 \%$ superior para o capim Mombaça. No entanto o requerimento pela $B$. decumbens, foi $38 \%$ superior. Fato também constatado na rebrota onde nos períodos iniciais o capim Mombaça apresentou maior produção (16,6\%) sob o mesmo requerimento. Demostrando assim que existem espécies que são mais eficientes em utilizar certos nutrientes em suas fases iniciais.

Outro fato importante descrito por Santos et al. (2002) foi que o nível crítico de $\mathrm{P}$ no solo para as plantas foram em média 33\% menores aos 28 dias quando comparado com este nível aos 14 dias pós emergência, além de uma tendência de estabilização após os 42 dias de crescimento, após o corte os valores encontram-se próximos ao encontrado no desenvolvimento inicial 42 dias pós emergência. Destaca-se neste cenário a importância da adubação 
POSSAMAI, A.J. et al. Influência da adubação fosfatada e calagem na ecofisiologia de gramíneas forrageiras. PUBVET, Londrina, V. 8, N. 8, Ed. 257, Art. 1705, Abril, 2014.

fosfatada no plantio das gramíneas forrageira e doses de manutenção menores após o corte para manutenção da produtividade.

M.M. Carvalho et al. (1994) buscando o requerimento de fósforo para o estabelecimento de Andropogon gayanus e Setariasphacelataem solo argiloso forneceram cinco níveis $\mathrm{P}_{2} \mathrm{O}_{5}$ na forma de superfosfato simples $(0 ; 50 ; 100$; 200 e $400 \mathrm{~kg} / \mathrm{ha}$ ) mostrando que o Andropogon tem capacidade de crescer mesmo em solos com menores teores de $\mathrm{P}$, uma vez que apresentou crescimento relativo de parte aérea maior do que a Setária para a ausência de adubação. No entanto a resposta relativa do maior nível de aplicação (400 kg/ha) de $\mathrm{P}_{2} \mathrm{O}_{5}$ foi $32 \%$ superior à ausência de corretivo, enquanto a resposta do capim Setária foi apenas de 3\%.Concluíram ainda que a demanda de fósforo é maior para as plantas no $1^{\circ}$ corte, indicando que plantas jovens necessitam mais $P$, uma vez que ainda possuem o sistema radicular pouco desenvolvido, chegando aos níveis de indicação de $\mathrm{P}$ para que as plantas produzissem $90 \%$ do máximo possível de 141 e $90,5 \mathrm{~kg} / \mathrm{ha}$ de $\mathrm{P}_{2} \mathrm{O}_{5}$ para os 10 e $2^{\circ}$ corte do capim Andropogon, enquanto para o capim Setária 211 e172 $\mathrm{kg} / \mathrm{ha}$ de $\mathrm{P}_{2} \mathrm{O}_{5}$ para 010 e $2 \circ$ corte respectivamente.

Da mesma forma Corrêa e Haag (1993) com o intuito de definir os níveis críticos de $\mathrm{P}$ no solo para Brachiaria decumbens, Brachiaria brizantha e Panicum maximumjacq. Colonião, concluíram que no primeiro corte 50 dias após a germinação o nível crítico de $\mathrm{P}$ no solo foram 22; 08 e $20 \%$ respectivamente maiores do que estes níveis no segundo corte que foi realizado 30 dias após a rebrota.

Já Cecatoel al. (2008) buscando a influência da aplicação de $P$ em características produtivas, testaram diferentes fontes de fósforo (Fosfato de Yorin, Gafsa, e mistura de Superfosfato simples e Superfosfato triplo) em dosagem de $140 \mathrm{~kg}$ de $\mathrm{P}_{2} \mathrm{O}_{5}$ ha`1 em capim Mombaçaimplantado em latossolo amarelo distrófico e não encontraram diferenças significativas para o índice de área foliar (IAF). O peso de perfilho foi $14 \%$ menor em média para a pastagem que recebeu adubação fosfatada. No entanto o número de perfilhos foi $26 \%$ maior para adubação com Superfosfato simples e Superfosfato triplo, quando 
POSSAMAI, A.J. et al. Influência da adubação fosfatada e calagem na ecofisiologia de gramíneas forrageiras. PUBVET, Londrina, V. 8, N. 8, Ed. 257, Art. 1705, Abril, 2014.

comparado ao controle, assim o maior perfilhamento fornece um dossel forrageiro de melhor qualidade.

Assim como Lopes et al. (2011) que estudaram o efeito da adubação fosfatada na implementação de estilosantes Mineirão e capim-Xaraés em consórcio em um argilossolo com saturação de base de $60 \%$. As fontes de fósforo utilizadas foram superfosfato triplo e superfosfato simples e as doses de $\mathrm{P}_{2} \mathrm{O}_{5}$ foram: $25 ; 50 ; 100$ e $200 \mathrm{~kg} / \mathrm{ha}$. Constatam que há efeito crescente no comprimento e largura da lamina foliar até a dose de $200 \mathrm{~kg}$, no entanto a amplitude da resposta diminui a partir de $100 \mathrm{~kg}$ de aplicação. Da mesma forma que para o estilosantes Mineirão, no entanto para esta leguminosa a amplitude do aumento na área foliar diminui após $50 \mathrm{~kg} / \mathrm{ha}$. Foi verificado ainda número crescente de perfilhos do capim Xaraés e do número de plantas do estilosantes com o nível crescente de adubação, sendo que o maior aumento foi verificado no intervalo de $25-50 \mathrm{~kg} / \mathrm{ha}$ de $\mathrm{P}_{2} \mathrm{O}_{5}$. A Produção de matéria seca teve maior amplitude no intervalo de $25-50 \mathrm{~kg} / \mathrm{ha}$ (Gráfico 1).

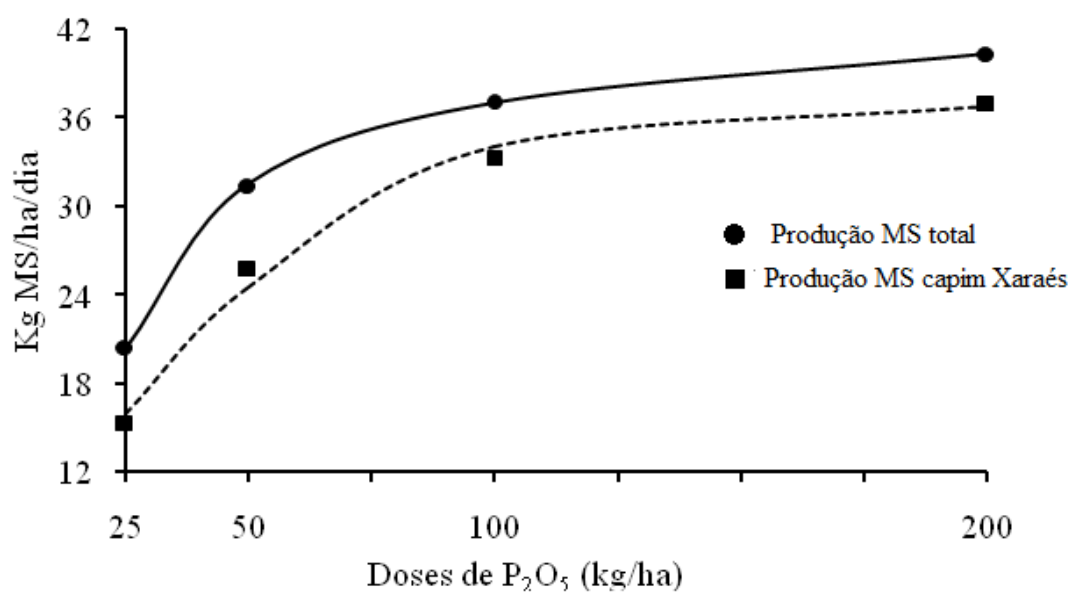

Gráfico 1 - Produção de MS/ha em diferentes dosagens de $\mathrm{P}_{2} \mathrm{O}_{5}$ na implementação do consócio capim-Xaraés e estilosantes Mineirão (Adaptado LOPES et al. 2011) 
POSSAMAI, A.J. et al. Influência da adubação fosfatada e calagem na ecofisiologia de gramíneas forrageiras. PUBVET, Londrina, V. 8, N. 8, Ed. 257, Art. 1705, Abril, 2014.

No mesmo sentido Rezende et al. (2011) verificaram o efeito da adubação de $\mathrm{P}_{2} \mathrm{O}_{5}$ no plantio e/ou em cobertura, no número e tamanho dos perfilhos, taxa de crescimento radicular e produção de MS aérea, para tanto utilizaram Brachiaria brizantha cv. Marandú e $100 \%, 50 \%, 25 \%$ e $0 \%$ de $\mathrm{P}_{2} \mathrm{O}_{5}$ no plantio e o restante foi aplicado em cobertura, além de um tratamento que não recebeu suplementação de fósforo. A adubação utilizada foi $500 \mathrm{~kg} / \mathrm{ha}$ de fosfato simples. A média da contagem de perfilhos foi maior para as plantas que receberam fósforo quando comparados com o grupo controle, 1.133,75 $\mathrm{x}$ 796,17 perfilhos $/ \mathrm{m}^{2}$ respectivamente. Entre os tratamentos que receberam $P$ não houve diferença para altura de perfilhos $(43,09 \mathrm{~cm})$, no entanto foi bem superior as plantas que não receberam $P(21,50 \mathrm{~cm})$. No crescimento radicular constatou-se um efeito $14,71 \%$ superior em comprimento radicular para os grupos que receberam $\mathrm{P}$, quando comparado com as plantas que não receberam P. A produção de matéria seca (MS) foi maior para o tratamento $100 \%$ no plantio, apresentando 2,58 ton./ha de MS a mais do que a tratamento controle. Assim a adubação de fósforo pode ser aplicada $100 \%$ no plantio potencializando a produção de MS, além de aumentar o número de perfilhos, melhorando a qualidade do dossel forrageiro.

Enquanto Ramos et al. (1997) utilizando menores doses em latossolo vermelho amarelo álico no Piauí na implementação de Brachiaria humidicola, Brachiaria decumbenscv Australiana, Brachiaria brizanthacv Marandú e Andropogon gayanuscv Planaltina, aplicando 0; 30 ,60; 90 e $120 \mathrm{~kg}$ de $\mathrm{P}_{2} \mathrm{O}_{5}$ na forma de superfosfato triplo, concluíram que o fósforo favoreceu linearmente todas as forrageiras especialmente em sua fase de crescimento inicial e ainda que a produção máxima na época das chuvas seria alcançada com a dose de $68,8 \mathrm{~kg} / \mathrm{ha}$ e na estação seca do ano com dose de $90 \mathrm{~kg} / \mathrm{ha}$, não verificaram diferenças significativas para a interação da gramínea com as doses de $P$ ( $p=$ $0,05)$. O conteúdo de $P$ nas folhas das plantas foi crescente a medida que se aumentou a dose de adubação (Gráfico 2), mostrando que mesma apresentando a produção máxima em teores mais baixos de $\mathrm{P}$ a absorção do 
POSSAMAI, A.J. et al. Influência da adubação fosfatada e calagem na ecofisiologia de gramíneas forrageiras. PUBVET, Londrina, V. 8, N. 8, Ed. 257, Art. 1705, Abril, 2014.

P-lábil aumenta a medida que se aumenta a disponibilidade deste nutriente no solo.

O fato do acréscimo dos teores de $\mathrm{P}$ nas folhas (Gráfico 2) torna-se importante para forrageiras submetidas a uma correta estratégia de adubação que visa maximizar a produção de MS da forragem melhorando o dossel forrageiro, fornecendo por consequência, aos animais maiores teores de $P$, assim os níveis de inclusão na suplementação mineral deste elemento pode ser reduzida, levando a uma redução nos custos, uma vez que a deficiência de P é amplamente observada e tem maior importância econômica envolvendo animais em regime de pastejo (TOKARNIA et al. 1988).

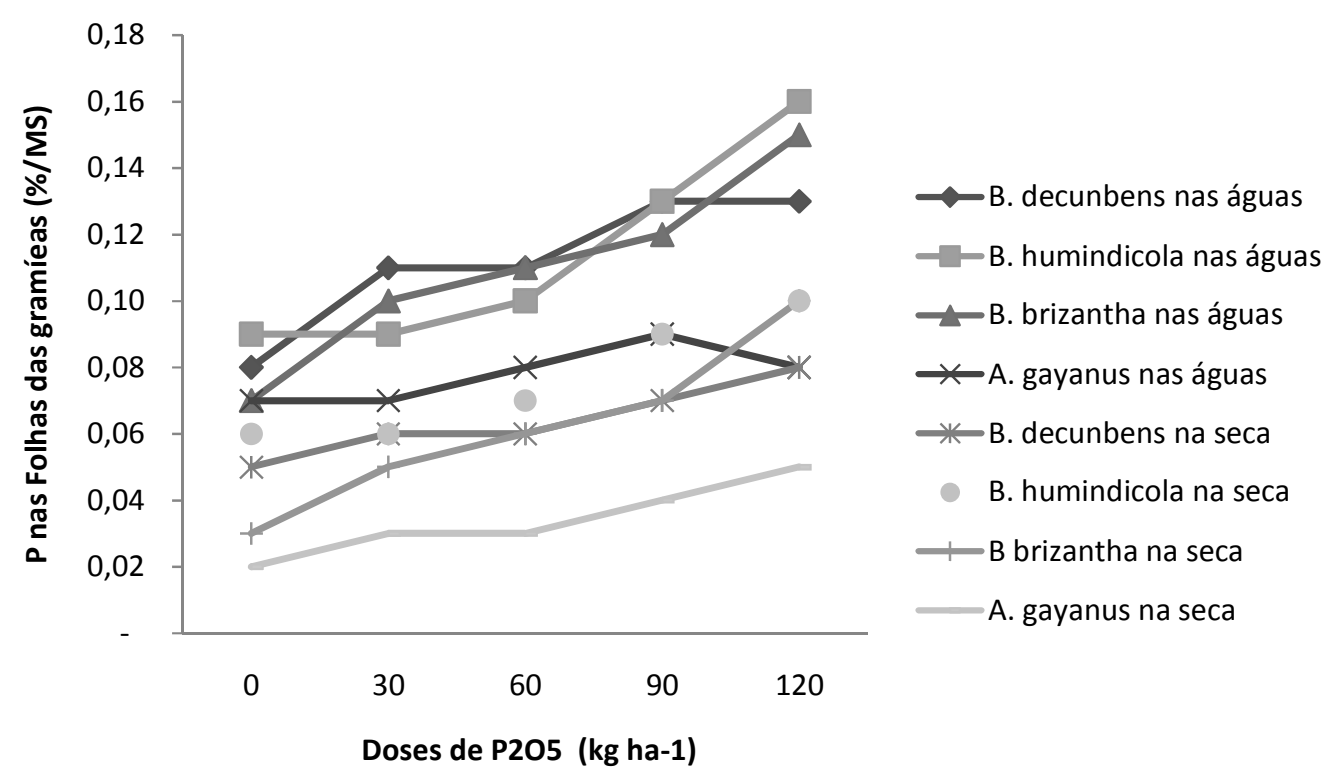

Gráfico 2 - Influência da adubação fosfatada com $\mathrm{P}_{2} \mathrm{O}_{5}$ nos teores de $\mathrm{P}$ na folha das gramíneas forrageiras na estação das chuvas e estação seca do ano. Adaptado de Ramos et al. (1997).

Barreto e Fernandes (2002), trabalhando como plantas de milho recendo $\mathrm{P}_{2} \mathrm{O}_{5}$ no plantio distribuídas em sulcos ou a lanço, observaram maiores teores de $\mathrm{P}$ foliar e maiores produções de grãos para as plantas que receberam a adubação a lanço em virtude da maior absorção neste sistema uma vez que se incorpora o adubo em um volume maior de solo que neste caso tinha baixa capacidade de adsorção, refletindo em um efeito positivo sobre o comprimento 
POSSAMAI, A.J. et al. Influência da adubação fosfatada e calagem na ecofisiologia de gramíneas forrageiras. PUBVET, Londrina, V. 8, N. 8, Ed. 257, Art. 1705, Abril, 2014.

e volume das raízes para as plantas que receberam adubação fosfatada a lanço de $90 \mathrm{~kg} \mathrm{ha}^{-1}$, estas produziram $32,46 \%$ a mais de massa de raízes especialmente raízes localizadas longe da planta o que aumenta a absorção de $\mathrm{P}$ e outros nutriente além de água quando comparados com a adubação no sulco. Os autores atribuem que a toxicidade e salinidade do $\mathrm{P}$ localizado no sulco de plantio e a baixa capacidade de adsorção do solo contribuíram para os resultados.

Como foi visto no gráfico 2 a composição de $\mathrm{P}$ nas folhas nas plantas é bem variável, isto faz com que a exigência das plantas por este nutriente seja distinta. Aanálise de solo (Quadro 1), portanto é uma ferramenta importante que irá auxiliar na escolha da forrageira com grau de exigência (Quadro 2) mais adequado para o solo disponívelpara que uma forrageira seja implantada com sucesso e que tenha uma produtividade compatível com seu potencial genético, maximizando a produção e reduzindo os custos da cadeia produtiva (SOUSA e LOBATO, 2003).

\begin{tabular}{|ccc|}
\hline \multirow{2}{*}{ Teor de argila (\%) } & \multicolumn{2}{c|}{ Disponibilidade de P no solo $\left(\mathrm{mg} / \mathrm{dm}^{3}\right)$} \\
\cline { 2 - 3 }$\leq 15$ & $\begin{array}{c}\text { Disponibilidade baixa Disponibilidade adequada } \\
\text { Espécies com baixa exigência }\end{array}$ \\
$\leq 15$ a 35 & 3,1 a 6,0 & $>9,0$ \\
35 a 60 & 2,6 a 5,0 & $>7,0$ \\
$>60$ & 1,6 a 3,0 & $>4,5$ \\
& 1,1 a 1,5 & $>2,0$ \\
$\leq 15$ & Espécies exigentes & $>15,0$ \\
15 a 35 & 5,1 a 10,0 & $>12,0$ \\
35 a 60 & 4,1 a 8,0 & $>6,0$ \\
$>60$ & 2,1 a 4,0 & $>3,0$ \\
& 1,1 a 2,0 & $>21,0$ \\
$\leq 15$ & Espécies muito exigentes & $>18,0$ \\
15 a 35 & 6,1 a 12,0 & $>10,0$ \\
35 a 60 & 5,1 a 10,0 & $>5,0$ \\
$>60$ & 3,1 a 5,0 & 2,1 a 3,0 \\
\hline
\end{tabular}

Quadro 1 - Interpretação do resultado da análise de Solo na profundidade de 0 a $20 \mathrm{~cm}$, obtido pelo método de Mehlich1, para o 3 grupos de gramíneas com diferentes exigências. Adaptado de SOUSA e LOBATO (2003) 
POSSAMAI, A.J. et al. Influência da adubação fosfatada e calagem na ecofisiologia de gramíneas forrageiras. PUBVET, Londrina, V. 8, N. 8, Ed. 257, Art. 1705, Abril, 2014.

Os efeitos positivos da adubação fosfatada na implementação de forrageiras são inegáveis e foram estudados por vários autores, já o efeito residual da adubação de P foi estudada por Oliveira et al. (2007) que aplicando adubação no estabelecimento de Brachiaria brizantha cv Marandú a produção da forrageira foi $13,08 \%$ e $9,09 \%$ maior para a adubação nos dois anos (totalizando de $160 \mathrm{~kg}$ de $\mathrm{P}_{2} \mathrm{O}_{5} \mathrm{ha}^{-1}$ ) utilizando Superfosfato simples e Superfosfato triplo respectivamente. No entanto quando se utilizou uma fonte menos solúvel (termofosfato magnesiano) com a adubação somente no plantio a produção foi $9,36 \%$ maior do que quando se utilizou a mesma fonte nos dois anos consecutivos, mostrando que a fonte de fosfato utilizado irá ditar o intervalo entre as aplicações do corretivo. Qualquer forma de adubação de $P$ proporciona uma produção adicional que supera os $100 \%$ quando comparado com as forrageiras que não receberam a correção.

\begin{tabular}{|c|}
\hline Pouco exigente \\
\hline Andropogon gayanus cv. Planaltina \\
Brachiaria decumbens \\
Brachiaria humidicola \\
Brachiaria ruziziensis \\
Paspalumatratumcv. Pojuca \\
\hline Exigentes \\
\hline Brachiaria brizantha cv. Marandu \\
Setariaanceps \\
Panicum maximum cv. Vencedor e cv. Centenário \\
\hline Muito exigente \\
\hline Panicum maximum cv. Colonião, cv. Tobiatã, \\
cv. Tanzânia-1, cv. Mombaça \\
Pennisetumpurpureum(Elefante, Napier) \\
Cynodonspp(Coast-Cross, Tifton)
\end{tabular}

Quadro 2 - Grau de exigência de $P$ no solo por gramíneas forrageiras. Adaptado de SOUSA e LOBATO (2003).

Os efeitos residuais da adubação fosfatada ainda foram estudados por Moreira et al. (2006) em cultura de capim elefante PennisetumpurpureumSchum. cv. Napier e concluíram que a adubação fosfatada na implementação desta gramínea seja a lanço ou incorporado na 
POSSAMAI, A.J. et al. Influência da adubação fosfatada e calagem na ecofisiologia de gramíneas forrageiras. PUBVET, Londrina, V. 8, N. 8, Ed. 257, Art. 1705, Abril, 2014.

linha de plantio tem efeito residual até os dois anos se mantidas a adubação de nitrogenada e potássica após os cortes.

\section{ACIDEZ NO SOLO E CALAGEM}

O conceito químico mais simples é capaz de ilustrar as ideias relacionadas a acidez do solo, onde ácidos são substâncias que em solução aquosa são capazes de liberar íons $\mathrm{H}^{+}$. Sendo três as principais causas da acidez no solo, a primeira ocorre naturalmente pela dissociação do gás carbônico, $\mathrm{O} \mathrm{H}^{+}$é transferido para a parte sólida do solo liberando um cátion trocável que é lixiviado junto com o bicarbonato. A segunda causa esta relacionada com a utilização de adubos amoníacos que ao reagirem com o solo liberam íons $\mathrm{H}^{+}$, por fim a terceira causa esta ligada a presença de alumínio que após a hidrolise liberam íons $\mathrm{H}^{+}$de acordo com a reação: $\mathrm{Al}^{3+}+3 \mathrm{H}_{2} \mathrm{O} \rightarrow 3 \mathrm{Al}(\mathrm{OH})_{3}+3 \mathrm{H}^{+}$(LOPES et al., 1990). Já para Hartwiget al. (2007) o excesso de alumino no solo é a principal causa de acidez nos solos brasileiros.

Os solos brasileiros especialmente os do Brasil Central, são ácidos, com teores elevados de alumínio e manganês, associadas a deficiência de cálcio, magnésio e fósforo, sendo atribuído a baixa taxa de enraizamento e prejuízos na absorção de água e nutrientes,como causadora das baixas de produtividade encontradas em solos ácidos. Para que ocorra a neutralização da acidez por produtos de rochas calcarias moída que são insolúveis, se faz necessário que as partículas do solo entrem em contato com o calcário, assim é imprescindível que se atente as particularidades de cada solo e a necessidade de incorporação deste corretivo agrícola (WEIRICH NETO et al., 2000).

Assim como para Caires et al. (2002) que descrevem a acidez no solo como um dos principais limitantes na produção de alimentos, dada a toxicidade do alumínio e manganês, e a baixa eficiência do crescimento de raízes, sendo a correção da acidez fundamental para melhorar a produção vegetal, mesmo que existam materiais genéticos mais tolerantes a acidez no solo, estes respondem positivamente a neutralização do $\mathrm{pH}$, com maior alongamento de raízes, a 
POSSAMAI, A.J. et al. Influência da adubação fosfatada e calagem na ecofisiologia de gramíneas forrageiras. PUBVET, Londrina, V. 8, N. 8, Ed. 257, Art. 1705, Abril, 2014.

acidez ainda interfere na absorção de alguns elementos como: N, P, K, Ca e Mg, por exemplo (FIGURA 1).

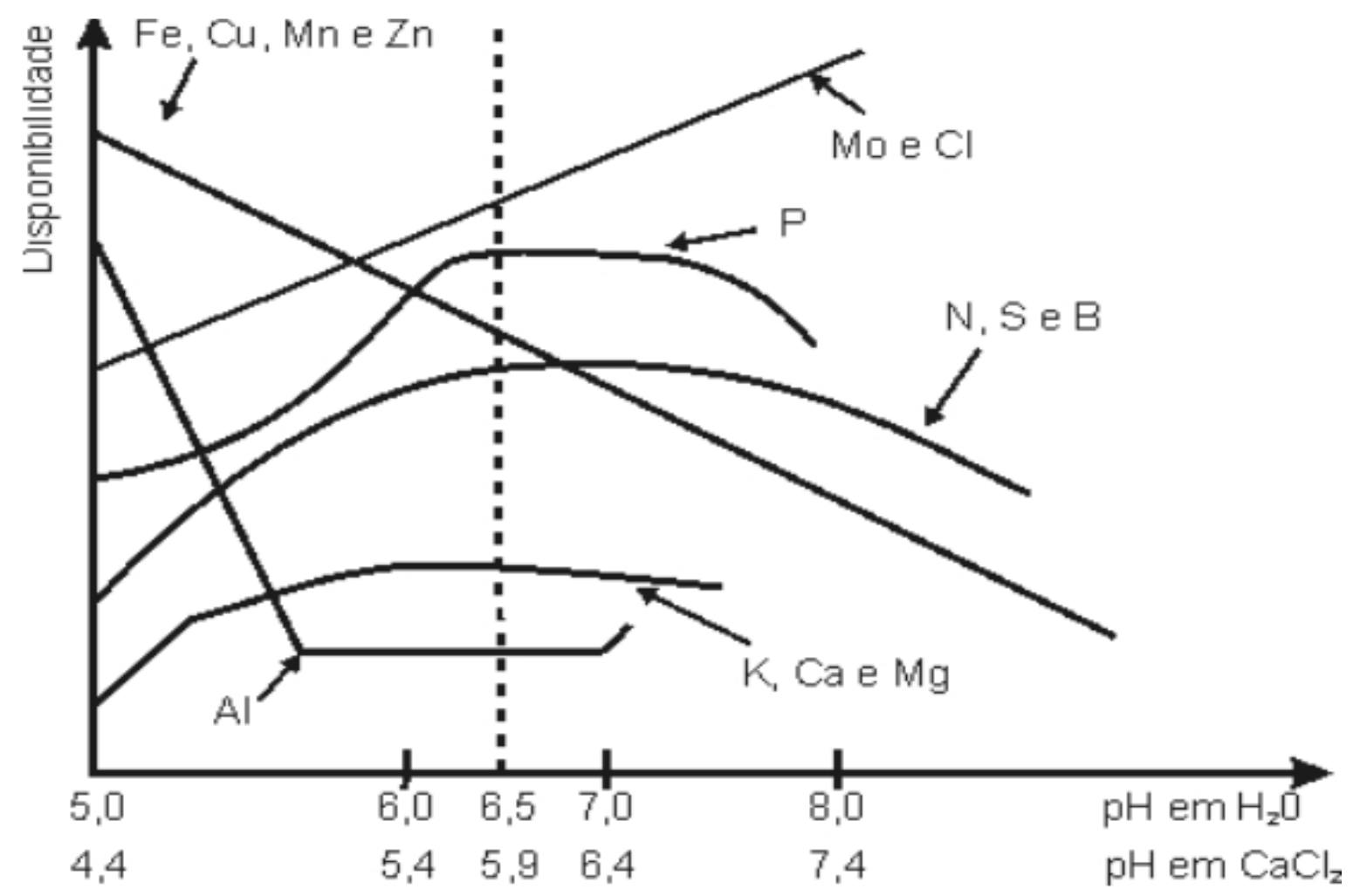

Figura 1 - disponibilidade de nutrientes do solo para as plantas em função do pH do solo. NICODEMO e LAURA (2001).

A disponibilidade de nutrientes no solo pode ser influenciada por vários fatores, dentre os quais podemos citar o valor de $\mathrm{pH}$, tipos de colóides, o equilíbrio entre a quantidade trocável no solo e a concentração do nutriente solubilizado no solo. Uma vez que no processo de absorção, ocorreminterações catiônicas nos sítios de adsorção e a concentração de íons nutrientes na solução do solo, constituem aspectos de grande importância na nutrição das plantas. A taxa de absorção de um nutriente pela planta depende dos cátions dissolvidos na solução de solo em equilíbrio dinâmico com os cátions do complexo de troca. Lembrando ainda que a absorção de um nutriente é 
POSSAMAI, A.J. et al. Influência da adubação fosfatada e calagem na ecofisiologia de gramíneas forrageiras. PUBVET, Londrina, V. 8, N. 8, Ed. 257, Art. 1705, Abril, 2014.

afetada também pela natureza dos cátions complementares, isto é, há influência de um íon adsorvido sobre a liberação de outro, para a solução do solo, a partir da superfície trocadora, além das relações que envolvem os cátions no solo (HERNANDES e SILVEIRA, 1998).

Outro fator importante que deve ser considerado é que a maioria dos solos ácidos apresentam baixos teores de P-Solução, devido a grande adsorção do nutriente por partículas do solo, limitando assim a eficiência da adubação fosfatada, desta maneira, a calagem é um passo fundamental para otimizar a utilização pelas plantas de nutrientes que estão sendo adicionados via adubação. O calcário neste cenário é o principal produto utilizado para elevar a saturação de bases no solo, servindo ainda como suprimento de cálcio, magnésio, influenciando no equilíbrio nutricional da planta (RAMOS et al., 1993).

Para se proceder a neutralização da acidez existe de modo básico três formas distintas de recomendação de calagem. O primeiro método relaciona-se a neutralização do alumínio trocável, o segundo critério que pode ser utilizado é a solução tampão SMP, utilizados em estados da região sul do Brasil, que consiste na mistura de uma amostra de solo com uma solução tampão e após faz-se a leitura em uma tabela obtendo a quantidade de calcário que deve ser aplicado, o ultimo método que pode ser adotado é de saturação de bases que é o critério mais teórico e flexível amplamente utilizado no território nacional, uma vez que na formula são utilizados os parâmetros referentes ao solo, exigência da cultura a ser implantada e corretivo, a equação é dada por: $N C\left(\frac{t}{h a}\right)=\frac{T\left(V_{2}-V_{1}\right)}{100} \times f$, onde: NC: necessidade de calcário, T: capacidade de troca de cátions a $\mathrm{pH} 7,0, \mathrm{~V}_{2}$ é a saturação de base desejada para cultura, $\mathrm{V}_{1}$ : representa a saturação de base atual do solo e $f:=100 /$ PRNT (poder relativo de neutralização total do corretivo (LOPES et al., 1990).

É importante considerar ainda, o tipo de calcário que será utilizado, uma vez que em solos que apresentem a análise de solo uma baixa relação $\mathrm{Ca}: \mathrm{Mg}$ deve-se optar pelo calcário calcitíco que é mais rico em cálcio, e solos que 
POSSAMAI, A.J. et al. Influência da adubação fosfatada e calagem na ecofisiologia de gramíneas forrageiras. PUBVET, Londrina, V. 8, N. 8, Ed. 257, Art. 1705, Abril, 2014.

apresentem uma relação alta, ou seja muito cálcio proporcionalmente a quantidade de magnésio optasse pelo calcário dolomitítico ou calcário magnesiano que possuem maior teor de magnésio. De um modo geral a proporção de Ca:Mg é 3:1 (LUZ et al., 2000).

Apesar do calcário ser o corretivo de acidez mais utilizado e desta maneira o qual será mais comentado nesta revisão, existem outros corretivos como silicatos de cálcio que podem aumentar o pH e possuem uma mobilidade maior no solo quando comparados com o calcário e o gesso que apesar de aumentar a quantidade de Ca no solo têm baixa atividade de neutralização de acidez, embora alguns técnicos o usem para tal fim (RAMOS et al., 2006).

Entretanto para que a correção seja efetiva se faz necessário proceder aincorporação do corretivo ao solo, uma vez que a aplicação em superfície não consegue promover adequada mistura do corretivo ao solo, e por se tratar de uma substância com baixa reatividade, a resposta da planta será menor. Sendo que as gramíneas de crescimento estoloníferos e rizomatosos permitem melhor eficiência no processo de incorporação do corretivo, quando comparado aquelas de crescimento cespitoso (LUZ et al. 2000).

No entanto Volpe et al. (2008) buscando estratégias de recuperação de pastagens encontraram resultados desfavoráveis para a utilização da grade isoladamente, uma vez que dependendo do tipo de solo a ação da grade pode prejudicar muito gramíneas já instaladas, principalmente em solos arenosos com equipamentos mais pesados, onde a profundidade de corte é maior, promovendo maior injurias a gramínea já instalada.

\section{UTILIZAÇÃO DE CALCÁRIO EM FORRAGEIRAS}

Luz et al. (2000) estudaram o efeito da calagem e do tipo de calcário sobre o capim Tobiatã implantado a 13 anos numa área de latossolo vermelho escuro argiloso, distrófico de $\mathrm{pH}$ em $\mathrm{CaCl}_{2}$ de 4,1, foi utilizado calcário calcinado e calcário convencional para elevar a saturação de base para 40\%, foi utilizado para incorporação uma grade leve e uma área em que não foi realizada esta operação. Os tipos de calcário não tiveram influência na 
POSSAMAI, A.J. et al. Influência da adubação fosfatada e calagem na ecofisiologia de gramíneas forrageiras. PUBVET, Londrina, V. 8, N. 8, Ed. 257, Art. 1705, Abril, 2014.

produção de MS, no entanto a incorporação mostrou-se efetiva com uma produção de $119,5 \mathrm{~kg}$ de MS/ha a mais que a não incorporação, nos 6 cortes procedidos de 4 a 6 meses após a calagem. O aumento na produção de MS foi seguido por um incremento na densidade dos perfilhos e não no aumento no número destes, mostrando que o peso é fator dos perfilhos é fator determinante na produção de MS de forragens.

Já Cruz et al. (1994) avaliaram o efeito da calagem sobre a produção de MS de Brachiaria brizantha cv. Marandú, Andropogon gayanus cv. Planaltina e Panicum maximum cv. Aruanã, aumentando a saturação de base inicial de $4 \%$ para $20 ; 36 ; 56 ; 68$ e $84 \%$ em um latossolo vermelho escuro de textura média e observaram que todas as gramíneas responderam positivamente a aplicação de calcário a medida que se aumentou a saturação de base aumentou a produção de MS da parte aérea da planta até o nível de 70\%.. Como pode ser observado no gráfico 3, que em saturações acima de $70 \%$ houve uma estabilização da produção, indicando para que estas espécies de forrageira tenham $90 \%$ da sua capacidade produtiva numa saturação de base de $70 \%$.

Tentando demonstrar os efeitos negativos da acidez no solo e concentração de alumínio no crescimento radicular de plantas, Caires et al. (2001) avaliaram, a elevação da saturação de base de 38\% para $70 \%$ em um latossolo vermelho distrófico de textura argilosa com aplicação de 4,5 toneladas de calcário dolomítico com $80 \%$ de PRNT, no crescimento radicular, área de enraizamento e densidade radicular de cevada, verificando que não houve diferença no tamanho, raio médio e densidade das raízes diante da elevação de saturação de bases. No entanto verificou-se que com a aplicação do corretivo sem incorporar as raízes cresceram mais superficialmente, quando comparado a parcelas que ocorreu incorporação do calcário ou onde foi aplicado gesso que promoveu maior distribuição das raízes no perfil do solo. Tornando estas plantas mais susceptíveis a sofrerem estresse hídrico uma vez que a maioria das raízes permanecem junto a superfície do solo. 
POSSAMAI, A.J. et al. Influência da adubação fosfatada e calagem na ecofisiologia de gramíneas forrageiras. PUBVET, Londrina, V. 8, N. 8, Ed. 257, Art. 1705, Abril, 2014.

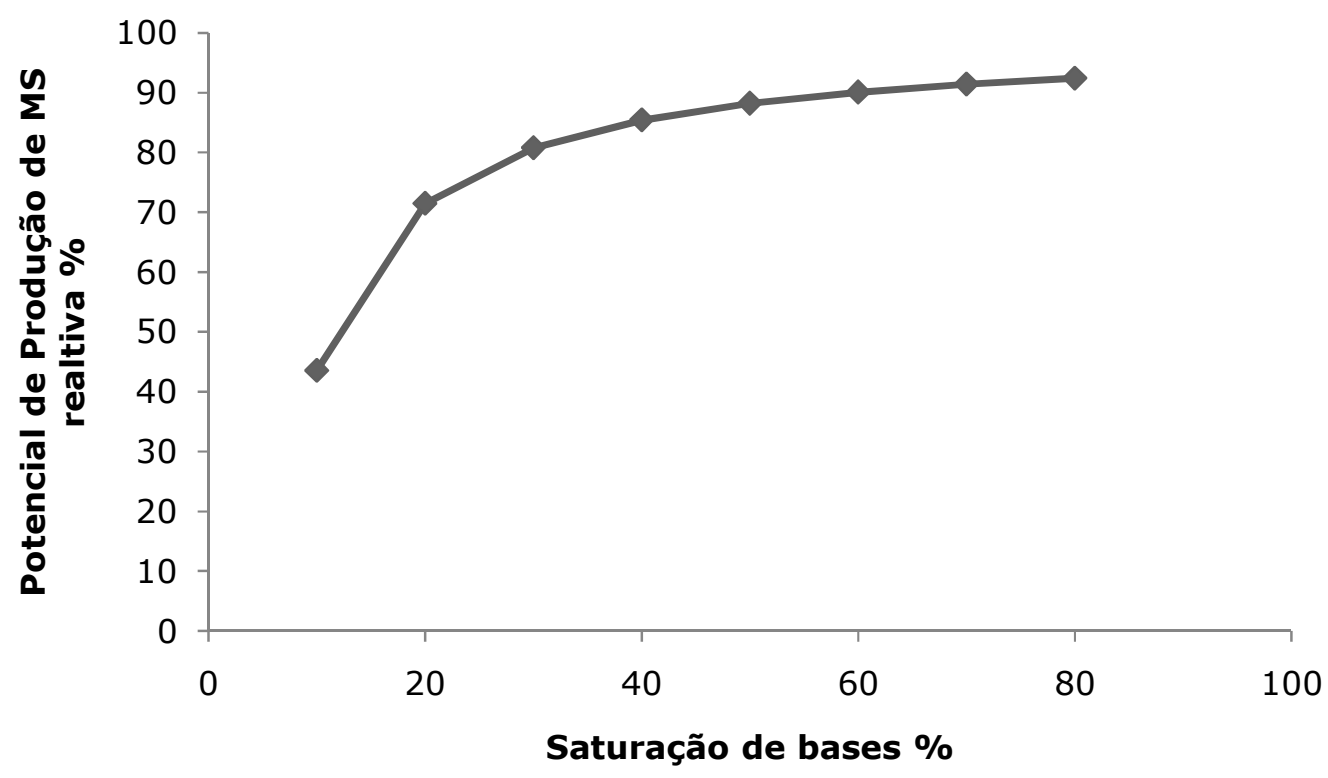

Gráfico 3-Potencial de produção de MS relativa, sob diferentes saturações de bases, em Brachiaria brizantha cv. Marandú, Andropogon gayanus cv. Planaltina e Panicum maximum cv. Aruanã. y =99,432 - 558,530/x. Adaptado Cruz et al. (1994).

Com o mesmo intuito de testar o efeito da calagem no crescimento radicular e produção de MS foliar na implantação de Brachiaria brizantha cv. Marandú em uma área degradada de pastagem Brachiaria decumbens, Volpe et al. (2008) elevaram a saturação de base de 10,6 para próximo a $20 \% \mathrm{em}$ NeossoloQuartzarênico de cerrado e obtiveram produção de MS da parte aérea das plantas $91 \%$ superior em relação a ausência de calagem e $32 \%$ a mais de MS de raízes para a calagem. $O$ incremento na produção de forragem esta ligada fortemente a maior produção de raízes, o que promove maior capacidade absortiva a esta planta.

Entretanto a resposta a calagem é muito variada, existindo trabalhos com respostas positivas, negativas ou sem influência, neste sentido Lima et al. (1999) avaliando o aumento da saturação de base em solo Podzólico vermelho escuro com utilização de calcário dolimítico com PRNT de $83 \%$, não encontraram correlação entre o aumento da saturação de base em até $100 \%$ para a produção de MS e teor de PB nas folhas de Cynodonspp (Tifton 85), cultivado em casa de vegetação. No mesmo sentido Sengiket al. (1996) não 
POSSAMAI, A.J. et al. Influência da adubação fosfatada e calagem na ecofisiologia de gramíneas forrageiras. PUBVET, Londrina, V. 8, N. 8, Ed. 257, Art. 1705, Abril, 2014.

encontraram aumento na produção de MS de capim Tanzânia em resposta a elevação das saturações de base.

Assim como Prado e Barion (2009) que testaram a calagem em CynodonsppcvTifton 85 em casa de vegetação com latossolo vermelho distrófico e verificaram que não houve diferença para elevação na saturação de base em até $70 \%$ para número de perfilhos, massa seca dos perfilhos ou área foliar, no primeiro corte. No entanto observou-se incremento na produção de massa seca, número de perfilhos e área foliar com comportamento quadrático para calagem no segundo e terceiro corte, com ponto de máxima produção a elevação da saturação de bases para $67 \%$.

Após levantamento técnico Souza et al. (2002), lançaram em um encarte técnico da EMBRAPA, recomendações para se elevar a saturação de base por meio de calagem de acordo com a exigência das plantas, sendo a saturação de base de 30 a $35 \%$ para gramíneas pouco exigentes, 40 a $45 \%$ para plantas exigentes e 50 a $60 \%$ para forragens muito exigentes. A classificação de acordo com a exigência foi descrita anteriormente no quadro 2 .

\section{UTILIZAÇÃO DA CALAGEM E ADUBAÇÃO FOSFATADA EM FORRAGEIRAS}

Nascimento et al. (2002) consideram que a acidez aliada a deficiência de P no solos brasileiros são os principais fatores limitante para produção de gramíneas e desta maneira estudaram a influência da calagem e doses de fósforo na produção de MS de Panicum maximum cv. Tanzânia. O solo do estudo foi classificado como latossolo vermelho amarelo, com $63 \%$ de argila e saturação de base $7,89 \%$, realizou-se calagem para elevação da saturação de base para 30 e $60 \%$ e uma parcela não recebeu calagem. Como fonte de fósforo foi utilizado, superfosfato simples, termofosfato de Yorin e hiperfosfato de Arad, na dosagem de $80 \mathrm{~kg}$ de $\mathrm{P}_{2} \mathrm{O}_{5}$ ha ${ }^{-1}$, verificaram que não houve influência para as doses de calcário aplicadas, mas a fonte de fósforo influenciou na produção, onde a fonte mais solúvel (superfosfato simples) proporcionou produção $66,16 \%$ maior do que a fonte menos solúvel (hiperfosfato de Arad). 
POSSAMAI, A.J. et al. Influência da adubação fosfatada e calagem na ecofisiologia de gramíneas forrageiras. PUBVET, Londrina, V. 8, N. 8, Ed. 257, Art. 1705, Abril, 2014.

Com o mesmo intuito Faquimet al. (1997) estudaram o efeito da calagem e diferentes fontes de fósforo além da utilização de gesso na absorção e níveis de nutrientes em plantas de Brachiaria brizanthacv Marandú e Andropogon Gayanuscv Planaltina, elevou-se a saturação de base para $50 \%$ em latossolo variação Una e aplicou-se três fontes de fosforo: Superfosfato simples, Termofosfato magnesiano de Yorin e fosfato de Araxá. Foi realizado o primeiro corte 70 dias pós-emergência. Na ausência de aplicação de $\mathrm{P}$ o crescimento foi afetado gravemente, tanto que só conseguiu-se realizar corte nestas forragens a partir dos 200 dias de cultivo e encontraram maior retenção de $\mathrm{P}$ para a adubação com termofosfato magnesiano, para $\mathrm{Ca}, \mathrm{Mg}$ e $\mathrm{S}$ observaram que o fosfato de Araxá seguido do termofosfato magnesiano proporcionaram maiores teores destes elementos nas folhas, contrastando com os dados de produção de MS que foi maior para superfosfato simples, sendo que a calagem não influiu nos níveis de $\mathrm{P}, \mathrm{Ca} \mathrm{Mg}$ e $\mathrm{S}$ no estudo.

Trabalhando com o mesmo tipo de solo Rossi et al. (1997) estudaram a interação como fonte de fósforo o superfosfato triplo e fosfato de Araxá, elevando a saturação de base para $50 \%$ no cultivo de Brachiaria brizantha cv. Marandú e verificaram que a produtividade da gramínea responde positivamente a adubação fosfatada, no entanto a amplitude do incremento de produtividade é menor a medida que se aumenta a dose de $\mathrm{P}$, encontrando valores de rendimento semelhante para dose de 50 a $345 \mathrm{~kg} / \mathrm{ha}$ de $\mathrm{P}_{2} \mathrm{O}_{5}$, sendo que no primeiro corte houve maior produção para o superfosfato triplo o que não ocorreu para os demais corte, mostrando que a com solubilidade menor o fosfato de Araxá demorou mais para fazer parte do P-Solução disponível a planta. Quando associou-se a calagem com a adubação fosfatado constatou-se que a produção máxima foi determinada quando se elevou a saturação de base para $50 \%(1,6$ tonelada de calcário ha-1 $)$, quando se utilizou fosfato de Araxá a dose mais efetiva de calcário foi 0,8 toneladas/ha, indicando que uma maior acidez aumenta a solubilidade desta fonte de $P$.

Estudando também os efeitos da calagem e adubação fosfatada em Brachiaria brizantha cv. Marandú, Paulino et al. (1994) utilizaram latossolo 
POSSAMAI, A.J. et al. Influência da adubação fosfatada e calagem na ecofisiologia de gramíneas forrageiras. PUBVET, Londrina, V. 8, N. 8, Ed. 257, Art. 1705, Abril, 2014.

amarelo de textura argilosa, 4 doses de fósforo $(0 ; 22 ; 44$ e $88 \mathrm{~kg}$ de $\mathrm{P} / \mathrm{ha}$ ) e três doses de calcário dolomítico corrigido para 100\% de PRNT (0; 1 e 2 toneladas/ha), verificaram que na ausência de calagem a produção máxima seria alcançada com utilização de $119 \mathrm{~kg}$ de $\mathrm{P} / \mathrm{ha}$, enquanto quando se utilizou 1 e 2 toneladas a produção máxima foi obtida com 94 e $100 \mathrm{~kg}$ de P/ha respectivamente, o que representa uma economia de até $25 \mathrm{~kg}$ de $\mathrm{P} / \mathrm{ha}$. O aumento na produção de MS em relação a calagem foi linear em função dos níveis de adubação fosfatada. Os maiores teores de PB nas folhas foram encontrados nos níveis intermediários de calagem e adubação fosfatada uma vez que o crescimento foliar foi menor do que nos níveis mais altos, ocorrendo menor efeito de diluição do nitrogênio na folha.

No mesmo sentido Macedo (2004) buscou os efeitos da calagem e da aplicação de fósforo na produção de matéria seca da parte aérea, raízes e relação raiz: parte aérea algumas das espécies mais cultivadas no cerrado, trabalhando em casa de vegetação utilizando solo argiloso do Cerrado, cultivando $B$. decumbens e $B$. brizanthacv Marandú e Xaraés.

Tabela 1 Produção de massa verde e de raízes para gramíneas produzidas em solo de cerrado com calagem e adubação fosfatada. Adaptada de Macedo (2004).

\begin{tabular}{|c|c|c|c|c|c|}
\hline \multirow{2}{*}{ Crescimento } & \multirow{2}{*}{$\begin{array}{l}\text { Saturação } \\
\text { de bases }\end{array}$} & \multirow{2}{*}{$\begin{array}{l}\text { P no solo } \\
\left(\mathrm{mg} / \mathrm{dm}^{3}\right)^{\mathrm{A}}\end{array}$} & \multirow[t]{2}{*}{$\begin{array}{c}\text { B. } \\
\text { decumbenscvBasilisk }\end{array}$} & \multicolumn{2}{|c|}{$\begin{array}{l}\text { Brachiaria } \\
\text { brizantha }\end{array}$} \\
\hline & & & & Marandú & Xaraés \\
\hline \multirow[t]{3}{*}{$\begin{array}{c}\text { Parte aérea } \\
\text { g/vaso }\end{array}$} & $22 \%$ & $\begin{array}{l}2 \\
10\end{array}$ & $\begin{array}{l}2,3 \\
34,4\end{array}$ & $\begin{array}{l}3,5 \\
29,7\end{array}$ & $\begin{array}{l}4,6 \\
38,5\end{array}$ \\
\hline & $55 \%$ & 2 & 5,3 & 7,6 & 7,9 \\
\hline & & 10 & 33,8 & 32,2 & 36,7 \\
\hline \multirow{4}{*}{$\begin{array}{l}\text { Raízes } \\
\text { g/vaso }\end{array}$} & $22 \%$ & 2 & 0,4 & 0,9 & 1,0 \\
\hline & & 10 & 10,54 & 9,7 & 11,7 \\
\hline & $55 \%$ & 2 & 2,0 & 2,3 & 2,1 \\
\hline & & 10 & 8,8 & 9,1 & 10,2 \\
\hline
\end{tabular}

${ }^{\text {A }}$ Nível de P no solo na colheita extrator Mehlich 1. 
POSSAMAI, A.J. et al. Influência da adubação fosfatada e calagem na ecofisiologia de gramíneas forrageiras. PUBVET, Londrina, V. 8, N. 8, Ed. 257, Art. 1705, Abril, 2014.

No mesmo trabalho Macedo (2004) ainda apresentou dados da produção de matéria seca total em Brachiaria brizantha cv. Marandu, em um LE argiloso, em função de diferentes combinações de fontes de fósforo com dose de $120 \mathrm{~kg}$ de $\mathrm{P}_{2} \mathrm{O}_{5}$ ha $^{-1}$ de fosfato de Arad e superfosfato triplo, em níveis crescentes de calagem (Figura 2).

A variação dos resultados quando se trabalha com calagem de plantas forrageiras é também descrito por Gatiboniet al. (2000) que aplicaram fósforo e fizeram calagem para implantação de Loliummultiflorum(Azevém), Trifoliumvesiculosum(Trevo) e pastagem natural no estado do Rio Grande de Sul, a produção do azevém e da pastagem nativa, triplicou com adubação fosfatada mais não diferiu $(p<0,05)$ para a aplicação de calcário. No entanto a produção do trevo aumentou mais que $100 \%$ quando se utilizou fonte de fósforo associado a calagem em relação a utilização apenas da adubação fosfatada.

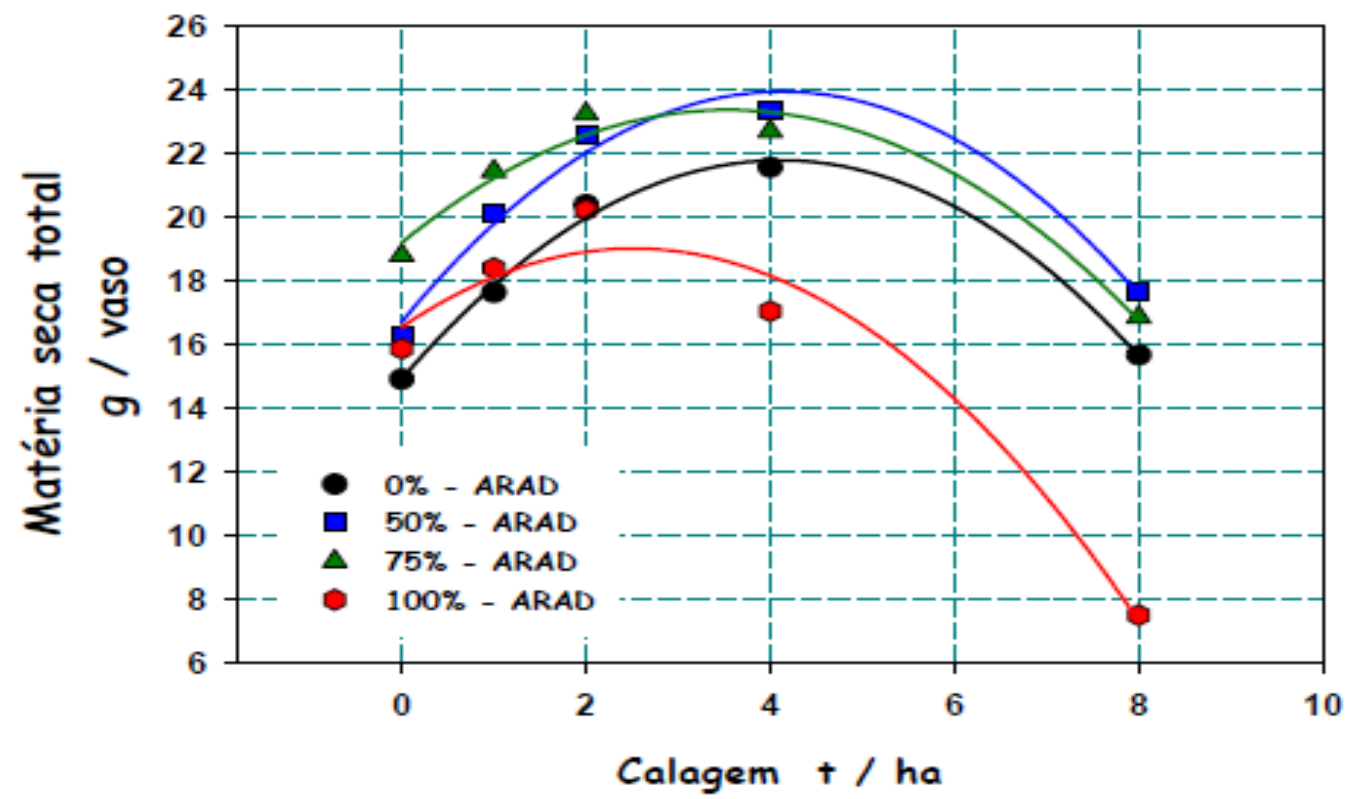

Figura 2 - Produção de MS por vaso de Brachiaria brizantha cv Marandú com superfosfato triplo e fosfato de Arad misturados me proporções distintas fazendo calagem. (MACEDO, 2004) 
POSSAMAI, A.J. et al. Influência da adubação fosfatada e calagem na ecofisiologia de gramíneas forrageiras. PUBVET, Londrina, V. 8, N. 8, Ed. 257, Art. 1705, Abril, 2014.

O incremento na produção como visto no decorrer deste trabalho é dependente de outros fatores, e que outros nutrientes especialmente $\mathrm{N}$ e $\mathrm{K}$ não sejam limitantes, tanto que Volpe et al (2008) avaliaram como estratégia de recuperação de pastagem degradada a utilização de calagem, calagem e adubação fosfatada, calagem adubação com PK e calagem com adubação PK e micronutrientes, e uma ultima área que recebeu calagem adubação PK, micronutrientes e o uso de consorcio com leguminosa, e observaram que a produção de MS na pastagem que recebeu calagem mais fósforo foi praticamente o dobro em relação a somente calagem, no entanto essa produção foi superada em $14,9 \%$ nas plantas que recebem adubação PK e micronutrientes, esta por sua vez sendo $15 \%$ inferior a produtividade alcançada para calagem, adubação PK, micronutrientes e consorcio com leguminosas. Fato este indica que apesar da acidez e deficiência de $\mathrm{P}$ serem de grande magnitude para os solos brasileiros, a deficiência de outros nutrientes pode limitar a resposta da planta a adubação fosfatada ou a calagem, assim a máxima produção vegetal é alcançada seguindo-se as recomendações agronômicas baseadas na análise de solo e no potencial de crescimento e exigência da forrageira.

\section{CONCLUSÃO}

O fósforo é um elemento fundamental para a planta, existem varias fontes deste elemento do mercado com potencial para utilização, sua aplicação promove respostas crescentes em várias culturas, no entanto a medida que se aumenta a dosagem diminui-se a amplitude do aumento da produção de biomassa. Os requerimentos deste elemento pelas plantas variam. Desta maneira a escolha da gramínea tem que levar em consideração a disponibilidade do $\mathrm{P}$ no solo através de analise previa.

A acidez no solo é prejudicial ao desenvolvimento das plantas, o corretivo mais utilizado é o calcário, a escolha do tipo de calcário, bem como a quantidade que se tem de aplicar deve ser baseada na análise de solo bem como no grau de exigência da gramínea cultivada. A aplicação isolada de 
POSSAMAI, A.J. et al. Influência da adubação fosfatada e calagem na ecofisiologia de gramíneas forrageiras. PUBVET, Londrina, V. 8, N. 8, Ed. 257, Art. 1705, Abril, 2014.

calcário promove resultados varáveis, sendo influenciado por outros fatores relacionados principalmente com a disponibilidade de outros elementos.

\section{BIBLIOGRAFIA CONSULTADA}

BARRETO, A. C.; FERNANDES, M. F. Produtividde e absorção de fósforo por plantas de milho em função de doses e modos de aplicação de adubo fosfatado em solo de tabuleiro costeiro, Revista Brasileira de Ciência do Solo, n. 26, p. 151-156, 2002.

BERNARDI, A. C. de C.; CARDOSO, R. D. Produção de matéria seca pela alfafa em função da Solubilização do fósforo da rocha fosfática em mistura com Zeólita: resultados de 11 cortes. In: Congresso Brasileiro de Ciência do Solo, XXXIII, Uberlândia, 2011, Anais... Uberlândia 2011.

CAIRES, E. F.; BARTH, G.; GARBIO, F. J.; KUSMAN, M. T. Correção da acidez do solo, crescimento radicular do milho de acordo com a calagem de superfície no plantio direto. Revista Brasileira de Ciência do Solo, v. 26, n. 4, p. 1011 - 1022, 2002.

CAIRES, E. F.; FELDHAUS, I. C.; BLUM, J. Crescimento radicular e nutrição da cevada em função da calagem e aplicação de gesso. Bragantia,v. 60, n.3, p. 213-223, 2001.

CARVALHO, M. M.; FREITAS, V. de P.; CRUZ-FILHO, A. B. da. Requerimentos de fósforo para o estabelecimento de duas gramíneas em um solo ácido. Pesquisa Brasileira Agropecuária, v. 29, n. 2, p. 199-209, 1994.

CECATO, U.; SKROBOT, V. D.; FAKIR, G. R.; BRANCO, A. F.; GALBEIRO, S.; GOMES, J. A. N. Perfilhamento e características estruturais do capim-Mombaça, adubado com fontes de fósforo, em pastejo. Acta Scientiarum Animal Science, v.30, n. 1, p. 1- 7, 2008.

CORRÊA, L. de A.; HAAG, H. P. Níveis críticos de fósforo no estabelecimento de gramíneas forrageias em latossolo vermelho-amarelo, Álico: I ensaio em casa de vegetação. Science Agrícola, v. 50, n. 1; p. 99-108, 1993.

CRUZ, M. C. P. da; FERREIRA, M. E.; LUCHETTA, S. Efeito da calagem sobre a produção de matéria seca de três gramíneas forrageira, Pesquisa Agropecuária Brasileira, v. 29, n. 8, p. 1303-1312, 1994.

FAQUIN, V. PASSOS, R. R.; VILLA, M. R.; CURI, N.; EVANGELISTA, A. R. Absorção e acumulação de nutrientes por gramíneas forrageiras sob influência de fontes de Fósforo e correção do solo, Revista Brasileira de Zootecnia, v. 26, n. 2, p. 219-226, 1997.

FRANÇA, A. F. S.; HAAG, H. P. Carência nutricional de Panicum maximumjacq. Tobiatã. In: Nutrição mineral de gramíneas tropicais, Anais da Escola Superior de Agronomia Luiz de Queiroz, v. 42, p. 83-95, 1985.

GATIBONI, L. C.; KAMINSKI, J. PELLEGRINI, J. B. R.; BRUNETTO, G.; SAGGIN, A.; FLORES, J. $P$. C. Influência da adubação fosfatada e da introdução de espécies forrageiras de inverno na oferta de forragem de pastagem natural, Pesquisa Agropecuária Brasileira, v. 35, n. 8, p. 1663-1668, 2000.

HARTIWIG, I.; OLIVEIRA, A. C. de; CARVALHO, F. I. F. de; BERTAN, I.; SILVA, J. A. G. da; SCMIDT, D. A. M.; VALÉRIO, I. P.; MAIAS, L. C.; FONSECA, D. A. R.; REIS, C. E. S. dos. Mecanismos associados ao mecanismo de tolerância de alumínio em plantas. Ciência Agraria Londrina, v. 28, n.2, p. 219-228, 2007.

HERNANDEZ, R. J. M.; SILVEIRA, R. I. Efeitos da saturação por bases, relações Ca:Mg no solo e níveis de fósforo sobre a produção de material seco e nutrição mineral do milho ZeamaysL. ScientiaeAgricola, v. 55, n. 1, p. 79-85, 1998.

IBGE. Censo Agropecuário 2006. Rio de Janeiro, p. 777, 2010. 
LIMA, M. Y. S. M.; SENGIK, E. CECATO, U.; SCAPIM, C. A.; Produção de matéria seca e teor proteico da gramínea tifton 85 (Cynodon spp.) cultivada em diferentes níveis de saturações de bases, Acta Scientiarum, v. 21, n. 3, p. 555-558, 1999.

LOPES, A. S.; SILVA, M. de C.; GUILHERME, R. L. G. Acidez no solo e calagem, Boletim técnico ANDA, $3^{a}$ ed. 19p, São Paulo - SP, 1990.

LOPES, J.; EVANGELISTA, A. R.; PINTO, J. C.; QUEIROZ, D. S.; MUNIZ, J. A. Doses de fósforo no estabelecimento de capim-xaraés e estilosantes Mineirão em consórcio. Revista Brasileira de Zootecnia, v. 40, n. 2, p. 2658-2665, 2011.

LUZ, P. H. de C.; HERLING, V. R.; BRAGA, G. J.; VITTI, G. C.; LIMA, C. G. Efeitos de Tipos, Doses e Incorporação de Calcário sobre Características Agronômicas e Fisiológicas do CapimTobiatã (Panicum maximum Jacq.). Revista Brasileira de Zootecnia, v. 24, n. 4, p. 964970, 2000.

MACEDO, M. Adubação fosfatada em pastagens cultivadas com ênfase na região dos Cerrados. In: Fósforo na Agricultura Brasileira, Editado por Tsuioshi Yamada e Silvia Regina Stipp e Abdalla. POTAFOS, Piracicaba, SP, Capitulo 14, p. 359 - 396, 2004

MACEDO, M. C. M.; KICHEL, A. N.; ZIMMER, A. H. Degradação e alternativas de recuperação e renovação de pastagens. EMBRAPA Gado de Corte - CNPGC, Campo Grande- MS, 4p. Documento 62,2000.

MARTINS, L. E. C, Respostas fisiológicas, metabólicas, estruturais e produtivas do capim Marandú às disponibilidade de Fósforo e Zinco. ESALQ, 2010, 53p, Dissertação (Mestrado em Solos e Nutrição de Plantas). ESALQ - Piracicaba, 2010.

NASCIMENTO, J. L. do; ALMEIDA, R. de A.; SilvA, R. S. M.; MAGALHÃES, L. A. F. Níveis de calagem e fontes de fósforo na produção Do capim Tanzânia (Panicum maximumJacq. cv. Tanzânia). Pesquisa Agropecuária Brasileira, v. 32, n. 1, p. 7-11, 2002.

NICODEMO, M. L. F.; LAURA, V. A. L. Elementos minerais em forrageiras: formas químicas, distribuição e biodisponibilidade. Embrapa Gado de Corte - Campo Grande - MS, Documento 115, 39p, 2001.

NOVAIS, R. F. de; SMYTH, T. J.; Formas de Fósforo no sistema solo-planta, In: Fósforo em solo e planta em condição tropicais. $1^{\text {a }}$ ed, 399p, Viçosa - MG, UFV, 1999.

OLIVEIRA, P. P. A.. OLIVEIRA, W. S. de; CORSI, M. Efeitos residual de fertilizantes fosfatados solúveis na recuperação de Brachiaria brizantha cV. Marandú em NeossoloQuartzarênico. Revista Brasileira de Zootecnia, v. 36, n. 6, p. 1715 - 1728, 2007.

PAULINO, M. F.; DETMANN, E.; SILVA, A. G. da; ALMEIDA, D. M de; VALENTE, É. E. L.; MACIEL, I. F. S.; NASCIMENTO, J. L. M. do; BITTENCOURT, J. A.; MARTINS, L. S.; BARROS, L. V. de; PAULA, N. F. de; MENDES, K. V. LOPES, S. A.; CARVALHO, V. V. de; Bovinocultura de alto desemprenho com sustentabilidade. In: VIII SIMCORTE, UFV - Viçosa MG, Anais ...p.183196, Viçosa, 2012.

PAULINO, V. T.; COSTA, N de L.; CARDELLI de LUCENA M. A. SCHAMMAS, E. A.; FERRARI JUNIOR, E. Resposta de Brachiaria brizantha cV. Marandú a calagem e a fertilização fosfatada em solo ácido. Revista PasturasTropicales, v. 16, n 2, p. 34 - 40, 1994.

PRADO, R. de M.; BARION, R. D.; Efeitos da calagem na nutrição e produção de massa seca do capim tifton 85, Pesquisa agropecuária tropical, v. 39, n. 3, p. 218-224, 2009.

RAMOS, G. M.; ITALiAno, E. C.; LEITE, G. G.; MELO, F. de B.; RiBEiRo, V. Q. Doses de fósforo na produção de gramíneas forrageiras em solos ácidos e de baixa fertilidade da região meio-norte do Brasil. Pasturastropicales, v. 19, n. 3 p. 24- 27, 1993. 
RAMOS, L. A.; NOLLA, A.; KORNDÖRFER, G. H. PEREIRA, H. S.; CAMARGO, M. S. de. Reatividade de corretivos da acidez e Condicionadores de solo em colunas De lixiviação, Revista Brasileira de Ciência do Solo, v. 30, p. 849-857, 2006.

REZENDE, A. V. de; LIMA, J. F. de; RABELO, C. H. S.; RABELO, F. H. S.; NOGUEIRA, D. A.; CARVALHO, M.; NOGUEIRA, D. C.; FARIA JUNIOR, A.; BARBOSA, L. de Á. Características morfofisiológicas da Brachiaria brizantha cv. Marandu em resposta à adubação fosfatada. Revista Agrarian, v. 4, n. 14, p. 335-343, 2011.

ROSANOVA, C. Estabelecimento de pastagens de cultivares de Panicum maximumjacq. em consórcio com sorgo forrageiro, sob fontes de fósforo, no cerrado tocantinense. UFT. 2008. 58p. Dissertação (Mestrado em Produção Vegetal), UFT, Gurupi, 2008.

ROSSI, C.; FAQUIN, V.; CURI, N.; EVANGELISTA, A. R. Calagem e fontes de Fósforo na produção do brachiarão e níveis críticos de Fósforo em amostra de latossolo dos Campos das Vertentes -MG. Revista Brasileira de Zootecnia, v. 26, n. 6, p. 1083-1089, 1997.

ROSSI, C.; MONTEIRO, A. F. Doses de fósforo, épocas de coleta e o crescimento e diagnose nutricional nos capins braquiária e colonião. ScientiaAgricola, v.56, n.4, p.1101-1110, 1999.

SANTOS, H. Q.; FONSECA, D. M.; CANTARUTTI, R. B.; ALVAREZ V., V. H.; NASCIMENTO JÚNIOR, D. Níveis críticos de fósforo no solo e na planta para gramíneas Forrageiras tropicais, em diferentes idades. Revista Brasileira de Ciência do Solo, n. 1, v. 26, p. 173-182, 2002.

SENGIK, E.; MACHADO, A. O.; CECCATO, U.; PINTRO, J.C.; PEREIRA, L.A.F.P. Efeito de diferentes saturações de bases da terra na produção de matéria seca do capim Tanzânia (Panicum maximumJacq. Cv. Tanzânia) e do milho (Zeamays L.). Revista Unimar, v. 18, n. 3, p.505-512, 1996.

SOUSA, D. M. G. de; LOBATO, E. Adubação fosfatada em solos da região do cerrados. Encarte Técnico Informações Agronômicas, n. 102, 16p, 2003.

SOUSA, D. M. G. de; VILELA, L.; LOBATO, E.; SOARES, W. V. Uso de gesso, calcário e adubos para pastagens no cerrado, EMBRAPA Cerrados, Planaltina - DF, 22p, 2001.

TAIZ, L. ; ZEIGER, E. Livro de Fisiologia Vegetal, 3a ed. Porto Alegre - RS, Artmed, 2004.

TOKARNIA, C. H.; DÖBEREINER, J. \& MORAES, S. S. Situação atual e perspectiva da investigação sobre nutrição mineral em bovinos de corte no Brasil. Pesquisa Veterinária Brasileira, Rio de Janeiro, V.8, n.1/2, p. 1-16, jan./ jun. 1988.

VOLPE, E.; MARCHETTI, M. E.; MACEDO, M. C. M. ROSA JUNIOR, E. J. Renovação de pastagem degradada com calagem, adubação e leguminosa consorciada em NeossoloQuartzarênico, Acta Science Agronomy, v. 30, n. 1, p. $131-138,2008$.

WEIRICH NETO, P. H.; CAIRES, E. F.; JUSTINO, A.; DIAS, J. Correção da acidez do solo em função de modos de incorporações do calcário. Ciência Rural de Santa Maria, v. 30, n 2, p. 257- 261, 2000.

ZANINE, A. de M.; SANTOS, E. M.; FERREIRA, D. de J. Possíveis causas da degradação de pastagens, Revista Eléctronica de Veterinária, v 6, n. 11, 23p, 2005.

ZIMMER, A. H.; MACEDO, M. C. M.; Recuperação de pastagem degradadas. In: Seminários de Sensibilização do Programa ABC (Agricultura de Baixo Carbono). Embrapa Gado de Corte, 2010. 